\title{
Situs Masjid Agung Sewulan \\ (Sejarah dan Potensinya Sebagai Sumber Belajar Sejarah SMP/MTsN)
}

\author{
*Riska Wayu Ariyani \\ *Khoirul Huda
}

\begin{abstract}
Abstrak
Penelitian ini bertujuan untuk pembelajaran sejarah dalam konteks Situs Masjid Agung Sewulan di Desa Sewulan Kecamatan Dagangan Kabupaten Madiun. Dalam penelitian ini menggunakan metode pendekatan induktif dengan jenis penelitian deskriptif kualitatif. Sumber data yang digunakan dalam penelitian ini adalah sumber datar primer dan sumber data sekunder. Teknik pengumpulan data menggunakan teknik wawancara, observasi dan dokumentasi. Validasi yang digunakan untuk menguji kebenaran dan keabsahan data menggunakan triangulasi sumber. Hasil penelitian yang diperoleh yaitu di Masjid Agung Sewulan Kecamatan Dagangan Kabupaten Madiun termasuk dalam situs sejarah. Situs adalah tinggalan purbakala yang dapat ditemukan pada lokasi tertentu, atau tempat manusia bekerja dan meninggalkan sebagai ungkapan kebudayaan yang berlaku sesuai jamannya. Situs Masjid Agung Sewulan ini merupakan peninggalan yang berasal dari Kyai Ageng Basyariah atau yang dikenal dengan nama Bagus Harun. Meskipun di sekitar Masjid Sewulan masih banyak Masjid lain yang memiliki keunikan namun keunikan tersebut berbeda dengan Masjid Agung Sewulan, tidak menutup kemungkinan Masjid tersebut dapat digunakan sebagai potensi sumber belajar. Situs Masjid Agung Sewulan ini juga digunakan untuk beberapa kegiatan sosial, pendidikan dan kebudayaan. Masjid Agung Sewulan ini dapat digunakan sebagai sumber belajar khususnya mata pelajaran IPS, dalam materi peninggalan sejarah bercorak Islam. Masjid Agung Sewulan ini merupakan salah satu peninggalan yang bercorak Islam, sehingga dapat menjadikan siswa lebih memahami pentingnya belajar peninggalan sejarah.
\end{abstract}

\section{Kata Kunci : Situs, Masjid, Sumber Belajar}

\section{Pendahuluan}

Pulau Jawa adalah salah satu pulau yang ada di Indonesia, yang memiliki banyak keanekaragaman budaya dan agama. Keanekaragaman agama yang ada di Indonesia diantaranya adalah agama Islam, Kristen, Katolik, Hindu, Budha dan Khong Hu_Chu. Salah satu agama terbesar di Indonesia adalah agama Islam. Agama Islam datang di Indonesia pada saat pusat-pusat kekuasaan Hindu mengalami kemunduran. Selain itu masuknya agama Islam di Jawa memiliki dampak positif maupun dampak negatif.

Berbagai macam peninggalan bersejarah yang ada di pulau Jawa dijadikan sebagai situs. Situs merupakan kekayaan budaya yang sangat penting bagi pemahaman dan pengembangan sejarah. Pentingnya situs ini di tunjukan agar terhindar dari kerusakan dan kepunahan. Harapan yang ada agar situs sejarah dapat terawat dan dikembangkan menjadi objek belajar, serta diwariskan pada generasi 
muda dalam keadaan utuh dan baik.Salah satu bangunan bersejarah tersebut yaitu, Masjid Agung Sewulan di Desa Sewulan Kecamatan Dagangan Kabupaten Madiun.

Masjid Agung Sewulan ini banyak di kunjungi oleh masyarakat karena pada hari tertentu masjid Agung Sewulan ini di jadikan sebagai tempat bermunajat. Selain itu masjid Agung Sewulan ini juga merupakan situs sejarah. Sehingga masjid Agung Sewulan ini mendapat perhatian masyarakat, misalnya pada Bulan Ramadhan, banyak masyarakat yang berdatangan untuk menjalankan shalat taraweh, shalat malam, shalat lailatul Q'odar dan tadarus.

Selain itu pada hari kamis dan jum'at Masjid Agung Sewulan juga digunakan sebagai tempat beziarah. Banyak masyarakat luar desa yang berdatangan, rata-rata masyarakat yang datang memiliki tujuan tertentu. Namun banyak anggota masyarakat yang belum mengetahui secara jelas sejarah masjid Agung Sewulan Kecamatan Dagangan Kabupaten Madiun.

Disisih lain apabila menelaah pembelajaran Ilmu Pengetahuan Sosial (IPS) di satuan pendidikan SMP atau MTs dijumpai dengan materi yang lebih khusus yakni, dalam standar kompetensi (SK) memahami perkembangan masyarakat sejarah masa Hindu-Buddha sampai kolonial Eropa, dan lebih tepatnya pada kompetensi dasar (KD) peninggalan sejarah bercorak Islam di Indonesia. Kelas VII SMP atau MTs semester ganjil.

Namun buku-buku Ilmu

Pengetahuan Sosial (IPS) yang digunakan guru atau siswa, Sepengetahuan penulis, belum ada yang menulis atau memuat materi-materi yang menunjang memahami perkembangan masyarakat sejarah masa Hindu-Buddha sampai kolonial Eropa, dan lebih tepatnya pada kompetensi dasar (KD) peninggalan sejarah bercorak Islam di Indonesia.

Oleh karena itu, timbul pertanyaan apakah sejarah masjid Agung Sewulan di Desa Sewulan Kecamatan Dagangan Kabupaten Madiun memiliki potensi yang dapat digunakan sebagai sumber pembelajaran Ilmu Pengetahuan Sosial (IPS) SMP atau MTs. Oleh sebab, itu maka penelitian ini menarik untuk dilaksanakan.

\section{TUJUAN PENELITIAN}

1. Menganalisis sejarah masjid agung Sewulan di Desa Sewulan Kecamatan Dagangan Kabupaten Madiun.

2. Mendiskripsikan potensi masjid agung Sewulan di Desa Sewulan Kecamatan Dagangan Kabupaten Madiun.

\section{KAJIAN PUSTAKA}

\section{A. Situs}

\section{Pengertian Situs}

Situs adalah lokasi yang mengandung atau diduga mengandung benda cagar budaya termasuk lingkungan yang di perlukan bagi pengamananya (Brian, 1993: 67). Situs 
adalah tinggalan purbakala yang dapat ditemukan pada lokasi tertentu, atau tempat dimana manusia bekerja dan meninggalkan sisa pekerjaan melalui benda bangunan, atau struktur yang ditinggalkan sebagai ungkapan kebudayaan yang berlaku sesuai jamannya.

Situs cagar budaya yaitu lokasi yang berada di darat, dan atau di air yang mengandung benda cagar budaya, bangunan cagar budaya dan atau struktur cagar budaya sebagai hasil kegiatan manusia atau bukti kejadian pada masa lalu. (Undang-undang Cagar Budaya nomer 11 tahun 2010). Undang-undang cagar budaya (http:///www.djpr.depkumham.go.Id 20/03/2015: 20.42).

Berdasarkan pendapat di atas dapat ditarik kesimpulan bahwa situs cagar budaya adalah peninggalan sejarah, tempat, sisa-sisa kebudayan yang ditinggalkan manusia pada masa lampau. Yang dilindungi oleh undangundang Cagar Budaya.

\section{Jenis-Jenis Situs}

Jenis situs yang berada di Pulau Jawa, situs dapat di bedakan menjadi yaitu Menurut Abdullah T. dan Lipan A. B (2010: 110) mengatakan bahwa, terdapat jenis situs purba dengan di temukan keberadaan situs tersebut dari tanggal yang berbeda-beda di Jawa mengidentifikasin manusia purba. Jenis situs bangunan adalah tempat atau lokasi yang dijadikan situs sejarah. situs bangunan berupa masjid kuno, candi. Bangunan jaman purba, yang kini masih tinggal sebagai peninggalan kebudayaan purba, hanyalah terbuat dari batu dan bata. Bangunan ini sangat erat dengan keagamaan, jadi bersifat suci (Soekmono, 1973: 81).

Berdasarkan pendapat di atas dapat ditarik kesimpulan bahwa jenis situs Cagar Budaya yang ada dapat di bedakan menjadi dua yaitu: situs purba dan situs bangunan. Situs tersebut merupakan peninggalan yang ada pada kehidupan manusia jaman dulu.

\section{Fungsi Situs}

Fungsi situs adalah sebagai sumberdaya yang terbatas (finite), takterbarui (non moveble), tak dapat dipindah (non moveble) dan rapuh (vulnerable/fragile), sehingga diperlukan penanganan situs secara tepat dan benar (M.Brian, 1993: 87). Situs yang ada di Pulau Jawa ini berupa benda sehingga di butuhkan untuk merawat situs guna melestarikan situs tersebut.

Dari pendapat di atas dapat ditarik kesimpulan bahwa fungsi dari situs sejarah adalah sesuatu yang dapat digunakan. Misalnya situs masjid, yaitu untuk kehidupan sehari-hari. Baik untuk masyarakat, kegiatan sosial dan juga dapat digunakan untuk dunia 
pendidikan sebagai sumber belajar.

Fungsi lain situs selain untuk tempat belajar juga sebagai tempat hiburan atau kesenangan.

\section{B. Masjid}

\section{Pengertian Masjid}

Suherman (2012: 61) berpendapat bahwa istilah Masjid berasal dari bahasa Arab, dari kata "sajada, yasjudu, sajdan". Sajada artinya bersujud, patut, taat, serta tunduk dengan penuh hormat dan ta'dzim. Untuk menunjukan suatu tempat, kata sajada diubah bentuknya menjadi "masjidun" (Isim Makan) artinya tempat sujud menyembah Allah SWT.

Berdasarkan pendapat di atas bahwa masjid adalah tempat untuk menjalankan ibadah umat Islam, serta tempat untuk mendekatkan diri kepada maha pencipta, selain itu masjid juga dapat digunakan untuk melakukan kegiatan berdakwah pada masyarakat.

\section{Fungsi Masjid}

Quraish dalam Suherman (2013: 62) mengatakan bahwa dalam sepanjang sejarah perjalanannya, masjid yang pertama kali didirikan nabi (Masjid Nabawi) tidak kurang dari sepuluh fungsi yang diembannya yaitu sebagai berikut:

a. Tempat ibadah (shalat dan dzikir)

b. Tempat konsultasi dan komunikasi (masalah ekonomi, sosial dan budaya) c. Tempat pendidikan

d. Tempat santunan sosial

e. Tempat latihan militer dan persiapan alat-alatnya

f. Tempat pengobatan para korban perang

g. Tempat perdamaian dan pengadilan sengketa

h. Aula untuk menerima tamu

i. Tempat menawan tahanan

j. Pusat penerangan dan pembelaan agama

Dari berbagai pendapat di atas ada kesamaan pendapat Juliadi ( 2007: 11) fungsi masjid sebagai pusat segala aktivitas umat Islam menyatukan diri dalam persaudaraan cinta yang universal. Selain itu fungsi masjid tempat beribadah (shalat, zikir), konsultasi dan komunikasi berbagai masalah termasuk ekonomi, sosial, budaya, pendidikan, santunan sosial.

AECT, Merril dan Drop dalam Sitepu (2014: 19) sumber belajar adalah alat yang dimaksud sebagai sumber belajar itu termasuk audio, televisi, bahan-bahan grafis untuk papan individual dan kelompok, bahan pembelajaran yang direkam dan termasuk orang-orang yang membantu guru dalam mempersiapkannya.

Dari uraian di atas dapat diambil kesimpulan bahwa yang dimaksud potensi sumber belajar adalah segala sesuatu yang dapat dimanfaatkan untuk 
belajar, refrensi dalam sumber belajar tidak hanya buku paket yang dapat digunakan untuk sumber belajar. Jadi sumber belajar dapat berupa tempat, alat yang ada di sekitar lingkungan.

\section{Jenis- Jenis Sumber Belajar}

Sumber belajar itu terdapat di mana-mana dan beragam jenisnya. Setiap sumber memiliki peran yang berbeda atau sama dalam kegiatan belajar mengajar bergantung kepada bagaimana ia diprogramkan dan dimanfaatkan. Jenis-jenis sumber belajar dapat diuraikan sebagai berikut ini :

a. Manusia Sumber (Orang, Masyarakat)

Merupakan sumber belajar adalah orang atau masyarakat yang direncanakan dalam kegiatan belajar-mengajar, guru, konseler, administrator pendidikan, tutor dan sebagainya. Untuk kepentingan yang lain, dapat juga diambil dari luar sekolah, seperti misalnya kelompok masyarakat tertentu, tenaga ahli, seniman bahkan pedagang, dan sebagainnya yang biasanya tidak mempunyai dasar sebagai pengajaran/guru.

$$
\text { Kelompok masyarakat }
$$

tertentu dapat merupakan masyarakat pedesaan, masyarakat terasing, masyarakat pedagang kaki lima, masyarakat perantauan dan sebagainya dapat dijadikan contoh nyata dalam proses belajarmengajar.

b. Bahan pengajaran

$$
\text { Biasanya bahan ini berisi }
$$
pesan bahasa yang direncanakan sebagai sumber belajar dinamakan media pengajaran, yang meliputi : bahan cetakan, film stip, fotografi, audiotape, videotape, peta, globe, chart (table bagan) dan sebagainya yang biasanya merupakan kombinasi dari sumber yang ada.

Bahan pengajaran atau media pengajaran ada yang sepenuhnya disediakan untuk pengajaran dan proses belajar mengajar, tetapi juga dapat dimanfaatkan untuk keperluan hiburan. Misalkan program-program televisi "cerita untuk anak" atau film yang diputar untuk umum. Tetapi bahan-bahan tersebut harus mendapatkan penilaian, sehingga tidak menimbulkan ekses-ekses ke perluan pengajaran.

\section{Ilmu Pengetahuan Sosial (IPS) SMP/MTs}

1. Pengertian Ilmu Pengetahuan Sosial (IPS) SMP/MTs

Kata IPS adalah Ilmu Pengetahuan Sosial yang memiliki arti penyederhanaan atau disiplin ilmu sosial dan kegiatan dasar manusia yang ada dalam kehidupan. Somantri dalam Sapriya (2009: 11) 
mengatakan bahwa pendidikan IPS adalah seleksi dari disiplin ilmu sosial dan humaniora, serta kegiatan dasar manusia yang diorganisasikan dan disajikan secara ilmiah dan psikologis untuk tujuan pendidikan.

Alasan yang sangat kuat terhadap perlunya pendidikan IPS sebagai program pendidikan ilmu sosial adalah ilmu yang mengajarkan secara terpisah memberatkan siswa sekolah. Pendidikan IPS merupakan kemasan pengetahuan sosial yang telah dipertimbangkan secara psikologis untuk kepentingan pendidikan.

\section{Tujuan IPS SMP/MTs}

Standar kompetensi (SK) memahami perkembangan masyarakat sejarah masa HiduBuddha sampai kolonial Eropa, dan lebih tepatnya pada kompetensi dasar (KD) peninggalan sejarah bercorak Islam di Indonesia.

Berdasarkan beberapa tujuan di atas dapat menjelaskan tujuan pendidikan IPS menurut Nursid dalam Gunawan (2006: 18) tujuannya adalah membina anak didik menjadi warga negara yang baik, yang memiliki pengetahuan, dan kepedulian sosial yang berguna bagi dirinya serta bagi masyarakat dan Negara. Sedangkan secara rinci Oemar Hamalik merumuskan tujuan pendidikan IPS berorientasi pada tingkah laku para siswa, yaitu (1) pengetahuan dan pemahaman, (2) sikap hidup belajar, (3) nilai-nilai sosial dan sikap, (4) ketrampilan Comar dalam Gunawan (2006: 18).

\section{METODE PENELITIAN}

\section{A. Lokasi Penelitian}

Penelitian ini dilaksanakan di Masjid Agung Sewulan terletak di Desa Sewulan, Kecamatan Dagangan, Kabupaten Madiun. Hal ini dikarenakan Masjid Agung Sewulan merupakan salah satu tempat ziarah dan sumber belajar di Kabupaten Madiun. Tempat tersebut berisi situs bangunan cagar budaya. Situs masjid agung Sewulan berjarak $\pm 6 \mathrm{~km}$ dari Kota Madiun ke Desa Sewulan, Jl. Kyai Ageng Basyariyah nomor 10 RT 07/RW 02 Desa Sewulan Kecamatan Dagangan Kabupaten Madiun.

\section{B. Waktu Penelitian}

Penelitian ini dilaksanakan selama 6 bulan yaitu mulai bulan Februari sampai Juli

\section{Pendekatan dan Jenis Penelitian}

Penelitian ini menggunakan pendekatan kualitatif. Pendekatan kualitatif merupakan metode penelitian yang digunakan untuk meneliti pada kondisi obyek yang alamiah, dimana peneliti adalah sebagai instrumen utama, teknik pengumpulan data 
dilakukan secara trianggulasi, analisis data bersifat induktif, dan hasil penelitian kualitatif menekan pada makna (Sugiyono, 2008: 205). Pada dasarnya penelitian kualitatif digunakan dalam penelitian yang merujuk pada objek dan fenomena yang terjadi secara alami. Adapun data yang akan diperoleh akan bersifat deskriptif karena menggunakan pendekatan induktif.

Dalam penelitian ini menggunakan pendekatan induktif dimana peneliti melakukan pengamatan atas permasalahan yang ada di Masjid Agung Sewulan Kecamatan Dagangan Kabupaten Madiun. Kemudian menarik kesimpulan secara umum dengan dukungan dari beberapa informasi, sehingga data yang akan diperoleh akan bersifat deskriptif.

Jenis penelitian yang dilakukan yaitu jenis penelitian deskriptif. Bagian deskriptif dalam catatan data ini meliputi potret subjek, rekonstruksi dialog, deskripsi keadaan fisik, struktur tentang tempat, dan barang-barang lain yang ada di sekitarnya. Demikian juga, catatan tentang berbagai peristiwa khusus (termasuk siapa yang terlibat dengan cara bagaimana, gerak-geriknya, dan juga tingkah laku atau sikap penelitiannya) (Sutopo, 2002: 74).

Pendekatan ini cocok untuk meneliti tentang sejarah Masjid Agung Sewulan di Desa Sewulan Kecamatan
Dagangan Kabupaten Madiun. Potensi yang dimiliki oleh masjid agung Sewulan sebagai sumber belajar sejarah atau IPS. Penelitian ini dilaksanakan dengan menganalisis data yang diperoleh dari wawancara, dokumentasi, dan observasi langsung di lapangan.

\section{Sumber Data}

Lofland dan Lofland dalam Lexy J. Moleong (2012: 157), Sumber utama dalam penelitian kualitatif ialah kata, dan tindakan, selebihnya adalah data tambahan seperti dokumen dan lainlainnya. Menurut Sugiono (2013: 137), sumber data dapat dilakukan dalam berbagai setting, berbagai sumber dan berbagai cara. Bila dilihat dari settingnya, data dapat dikumpulkan pada setting alamiah (natural setting), Sumber data penelitian ini merupakan sumber data primer dan sumber data sekunder yang dapat menjelaskan informasi yang diperlukan dalam penelitian. Sumber data pada penulisan ini diperoleh dari:

1. Sumber Data Primer

Sumber data primer merupakan sumber data yang langsung memberikan data kepada pengumpul data (Sugiono, 2001: 129). Hal senada juga disampaikan oleh Umar (2011: 42) bahwa data primer merupakan data yang diperoleh dari sumber pertama baik dari individu atau perseorangan 
seperti hasil dari wawancara atau hasil pengisian kuisioner yang biasa dilakukan oleh peneliti.

Informan dari penelitian ini yaitu juru kunci Masjid Agung Sewulan Kecamatan Dagangan Kabupaten Madiun, Kepala Desa Sewulan dan Kecamatan Dagangan Kabupaten Madiun, beberapa guru mata pelajaran IPS (sejarah), para ziarah, sesepuh, serta masyarakat sekitar Masjid Agung Sewulan di Desa Sewulan Kecamatan Dagangan Kabupaten Madiun yang dipilih secara selektif.

2. Sumber Data Sekunder

Sumber data sekunder menurut Sugiono (2013: 137) adalah sumber yang tidak langsung memberikan data kepada pengumpul data. Sumber data sekunder yang digunakan dalam penelitian ini adalah sejarah masjid Agung Sewulan, data yang diperoleh dari Kecamatan Dagangan Kabupaten Madiun, berupa sumber data tertulis berasal dari arsip, dokumen, serta buku-buku yang diperoleh dari sejarah masjid Agung Sewulan Desa Sewulan , Kecamatan Dagangan, Kabupaten Madiun .

\section{E. Teknik Pengumpulan Data}

Menurut Sugiyono (2008: 224) teknik pengumpulan data merupakan langkah yang paling strategis dalam penelitian, karena tujuan utama dari penelitian adalah mendapatkan data. Tanpa mengetahui teknik pengumpulan data, maka peneliti tidak akan mendapatkan data yang memenuhi standar data yang ditetapkan. Pengumpulan data dilakukan dengan wawancara, observasi, dan dokumentasi tertulis atau arsip.

1. Wawancara

Sukmadinata (2012: 216) berpendapat bahwa wawancara atau interviu (interview) merupakan salah satu bentuk teknik pengumpulan data yang banyak digunakan dalam penelitian deskriptif kualitatif dan deskriptif kuantitatif. Wawancara dilaksanakan secara lisan dalam pertemuan tatap muka secara individual. Adakalanya juga wawancara dilakukan secara kelompok, kalau memang tujuanya untuk menghimpun data dari kelompok seperti wawancara dengan satu keluarga, pengurus yayasan, atau Pembina pramuka. Penggunaan metode tersebut karena peneliti akan melakukan wawancara kepada informan yang dianggap sebagai salah satu sumber yang bisa menjawab masalah penelitian.

Peneliti pun perlu menjelaskan kepada responden tentang maksud dan tujuan penelitian ini. Sebelum mengadakan wawancara 
terlebih dahulu peneliti menyusun pedoman wawancara. Metode tersebut akan mampu menjawab sejarah masjid Agung Sewulan dan potensinya sebagai sumber belajar Ilmu Pengetahuan Sosial.

2. Observasi Langsung

Hal senada juga disampaikan oleh Nazir (2009: 175) observasi langsung atau dengan pengamatan langsung adalah cara pengambilan data dengan menggunakan mata tanpa ada pertolongan alat standar lain untuk keperluan tersebut. Teknik observasi digunakan untuk menggali data dari sumber data yang berupa peristiwa, tempat atau lokasi dan benda serta tekanan gambar yang dilakukan secara langsung maupun tidak langsung.

Observasi yang dilakukan dalam penelitian ini adalah peneliti mengamati keberadaan masjid agung Sewulan guna mengetahui sejarah dan potensinya sebagai sumber belajar Ilmu Pengetahuan Sosial. Dalam observasi ini peneliti mendatangi lokasi dan mengamati secara langsung kondisi aktual yang ada di masjid agung Sewulan Desa Sewulan Kecamatan Dagangan Kabupaten Madiun.

3. Dokumentasi Tertulis/Arsip

Menurut Sugiyono (2006: 329) menyatakan bahwa dokumen merupakan catatan peristiwa yang sudah berlalu. Dokumen biasanya bisa berbentuk tulisan, gambar, atau karya-karya monumental dari seseorang. Dokumen berbentuk tulisan misalnya, catatan harian, sejarah kehidupan, ceritera, biografi, peraturan, kebijakan. Dokumen berbentuk gambar, misalnya, foto, gambar hidup, sketsa, dan lain-lain. Dokumen yang berbentuk karya misalnya, karya seni, yang dapat berupa gambar, patung, film, dan lainlain. Studi dokumen merupakan pelengkap dari penggunaan metode observasi dan wawancara dalam penelitian kualitatif.

\section{F. Instrumen Penelitian}

Dalam penelitian kualitatif, yang menjadi instrumen atau alat penelitian adalah peneliti itu sendiri (Sugiono,2012: 305).

Dalam penelitian kualitatif instrumen utamanya adalah peneliti itu sendiri, namun selanjutnya setelah fokus penelitian menjadi jelas, maka kemungkinan akan dikembangkan instrumen penelitian sederhana, yang diharapkan dapat melengkapi data, dan membandingkan dengan data yang telah ditemukan melalui observasi dan wawancara (Sugiono, 2012: 307).

\section{G. Prosedur Penelitian}

Penelitian ini tentang sejarah masjid agung Sewulan, potensi sumber 
belajar yang dimiliki oleh masjid agung Sewulan di Desa Sewulan Kecamatan Dagangan Kabupaten Madiun dilakukan selama 6 bulan. Penelitian dilaksanakan mulai dari bulan Februari sampai dengan bulan Juli tahun 2015. Tahapan dalam penelitian ini tersusun sebagai berikut:

\section{Tahap Persiapan}

Tahap awal dari penelitian ini merupakan bagian dari menetapkan fokus penelitian. Kegiatan ini dimulai dengan menetapkan tema dan judul yang akan menjadi obyek penelitian.

2. Tahap Penelitian

Tahapan yang selanjutnya merupakan tahapan penelitian. Pada tahapan ini dilakukan pengumpulan data, pengolahan data, dan analisis data. Dalam tahapan pengumpulan data peneliti mendapatkan data dari berbagai sumber. Sumber yang didapat merupakan hasil dari wawancara, sumber dokumen, dan pengamatan atau observasi secara langsung.

Dengan begitu data yang terkumpul akan mampu diolah secara baik dan benar oleh peneliti. Pengolahan data digunakan untuk mendapatkan deskripsi awal obyek penelitian. Setelah itu dilakukan analisis data untuk mempermudah dan mendapatkan validitas dari hasil data yang diperoleh. Tujuan analisis data memperdalam hasil temuan data yang diperoleh dan mampu mengetahui hasil awal sesuai dengan tujuannya. Jika diketemukan hasil yang kurang sesuai maka akan dilakukan analisis yang berkelanjutan. Hal ini dilakukan agar hasil penelitian benar-benar maksimal dan sesuai kenyataan.

3. Tahap Laporan

Pada tahap akhir merupakan tahap penyelesaian laporan atau penyajian data. Penyusunan laporan didasarkan pada hasil analisis data yang sudah didapatkan pada tahap sebelumnya. Laporan atau sajian dilakukan secara benar dan tersusun sistematis. Selain itu data yang disajikan merupakan data yang sesuai dengan fakta dan dapat dipertanggung jawabkan kebenarannya.

\section{H. Teknik Keabsahan Data}

Untuk mendapatkan data yang valid dalam penelitian ini, peneliti menggunakan teknik validitas data sebagai berikut:

1. Triangulasi metode adalah pengumpulan data yang sama dengan menggunakan metode pengumpulan data yang berbeda, serta diusahakan mengarah pada sumber data yang sama untuk menguji kemantapan informasi. Penggunaan metode pengumpulan 
data yang berbeda, dan bahkan lebih jelas untuk diusahakan mengarah pada sumber data yang sama untuk menguji kemantapan informasinya. Misalnya, untuk memantapkan validitas data mengenai suatu keterampilan seseorang dalam bidang tertentu (Sutopo, 2002: 80).

2. Triangulasi sumber data adalah mengumpulkan data dari berbagai sumber data digunakan untuk menguji kebenaran tentang pelaksanaan pembelajaran bahasa Indonesia. Cara ini mengarahkan peneliti agar di dalam mengumpulkan data, ia wajib menggunakan beragam sumber data yang tersedia. Triangulasi sumber data yang memanfaatkan jenis sumber data yang berbeda-beda untuk menggali data yang sejenis ( Sutopo, 2002: 79).

3. Reviu informan merupakan usaha pengembangan validitas penelitian. Digunakan untuk mereviu informan, apakah data hasil wawancara sudah valid dan sesuai dengan kesepakatan atau belum. Pada waktu peneliti sudah mendapatkan data yang cukup lengkap dan belum utuh dan menyeluruh, maka unitunit laporan yang telah disusunnya perlu dikomunikasikan dengan informannya, khususnya yang dipandang sebagai informan utama (Sutopo, 2002: 83).

Adapun secara singkat teknik trianggulasi sumber dapat dilihat dari bagan di bawah ini:

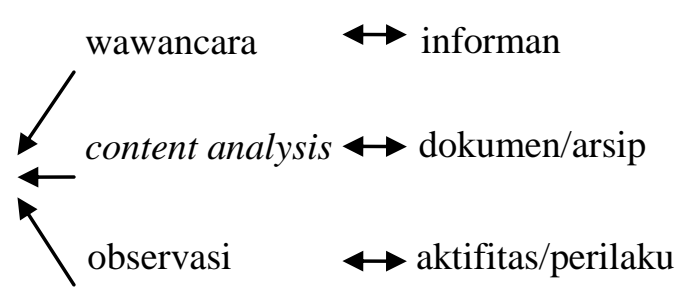

Bagan 3. 1. Trianggulasi Sumber (H. B. Sutopo, 2002: 80)

\section{Teknik Analisis Data}

Analisis data seperti pendapat Lexy J.Moleong (2011: 247) adalah proses analisis data dimulai dengan menelaah seluruh data yang tersedia dari berbagai sumber yaitu wawancara, pengamatan yang sudah dituliskan dalam catatan lapangan, dokumen pribadi, dokumen resmi, gamba, foto, dan sebagainya.

\section{Tahap Reduksi Data}

Dalam tahap reduksi data, peneliti melakukan proses seleksi, pemfokusan, penyederhanaan dan abstraksi data dari sumber penelitian. Reduksi data merupakan bagian dari proses analisis yang mempertegas, memperpendek, membuat fokus, membuang hal-hal yang tidak penting dan mengatur data sedemikian rupa sehingga simpulan penelitian dapat dilakukan. Peneliti melakukan tahap reduksi data dengan membaca secara 
cermat objek penelitian dan kemudian dibagi ke dalam kategori sesuai kajian yang peneliti amati.

2. Tahap Penyajian Data

Sajian data merupakan suatu rakitan organisasi informasi, deskripsi dalam bentuk narasi yang memungkinkan simpulan penelitian dapat dilakukan. Sajian ini merupakan rangkaian kalimat yang disusun secara logis dan sistematis. Tujuannya agar peneliti bisa memahami objek yang diteliti dan memberikan jawaban sesuai rumusan masalah penelitiannya. Hubungannya dengan tahap penyajian data, peneliti melakukan ringkasan yang relevan dengan bidang kajian yang diteliti. Hal ini dilakukan agar memudahkan peneliti dalam mengelompokkan dan menentukan simpulan.

\section{Tahap Penarikan Kesimpulan}

Tahap simpulan merupakan tahap akhir dalam analisis data ini. Berbagai data yang dibutuhkan untuk penarikan suatu simpulan mulai dianalisis secara lebih mendalam. Hal ini dilakukan agar penelitian kualitatif ini bisa dipertanggungjawabkan

kebenarannya.

Oleh karena itu dalam tahapan yang dilakukan merupakan suatu rangkaian tahapan yang memiliki keterkaitan. Adapun keterkaitan komponen antara tahap tersebut sebagai berikut:

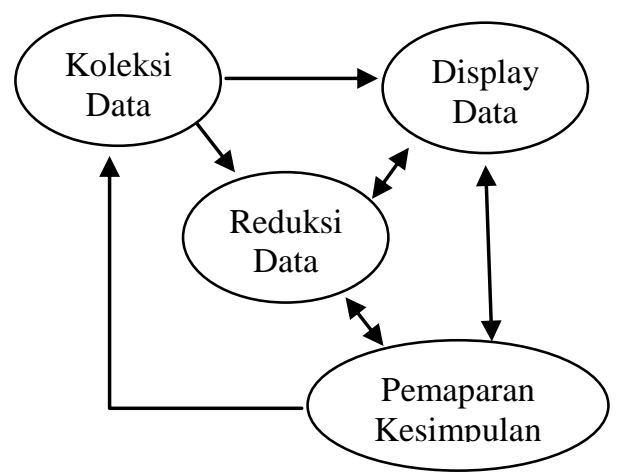

Bagan 3.2. Analisis Data Model Interaktif, Miles dan Huberman

(Sumber: Miles dan Huberman, 1992:20)

\section{Pembahasan}

A. Sejarah Masjid Agung Sewulan di Desa Sewulan Kecamatan Dagangan Kabupaten Madiun.

Masjid Agung Sewulan atau yang disebut dengan situs Sewulan merupakan salah satu peninggalan dari Kyai Ageng Basyariyah atau yang disebut Raden Mas Bagus Harun. Masjid Agung Sewulan ini terletak di Desa Sewulan jalan Masjid Al-Basyariyah RT 07/RW 02 Kecamatan Dagangan Kabupaten Madiun. Masjid Agung Sewulan ini didirikan pada tahun 1714 pada saat Kyai Basyariah atau yang disebut Raden Mas Bagus Harun ini mendapatkan hadiah babad tanah Sewulan dan Kyai Ageng Basyariah ini membuang payungnya.

Pada akhirnya Kyai Ageng Basyariah ini membangun Masjid 
dengan mencari tempat dimana payung itu berada akan di bangun sebuah Masjid. Setelah Kyai Ageng Basyariah mencari-cari maka bertemulah dengan kerangka dari payung tersebut akhirnya Kyai Ageng Basyariah mendirikan masjid dan yang sekarang disebut Masjid Agung Sewulan karena pembuatanya yang memerlukan waktu selama Seribu Bulan, untuk menjadikan sebuah Masjid tersebut.

Saat ini Masjid Agung Sewulan merupakan situs yang dilindungi dan mayoritas masyarakat Madiun sering menyebut Masjid Agung Sewulan dengan sebutan Situs Sewulan. Masjid Agung Sewulan ini dibangun di tempat yang sangat strategis.

Masjid Agung Sewulan dibangun dengan tujuan untuk, 1) mengenalkan agama Islam pada masyarakat Jawa khususnya masyarakat yang berada di Desa Sewulan. 2) Menyebarkan agama Islam atau mensiarkan agama Islam agar masyarakat mengerti akan pentingnya ibadah kepada Allah. Pada saat Kyai Ageng Basyariah mendirikan Masjid juga datang seorang penyiar agama Islam yang berasal dari Yogyakarta dan pada saat itu juga agama Islam berkembang di Desa Sewulan.

\section{B. Situs Masjid Agung Sewulan Sebagai} Cagar Budaya

Situs adalah tinggalan purbakala yang dapat ditemukan pada lokasi tertentu, atau tempat di mana manusia bekerja dan meninggalkan sisa pekerjaan melalui benda bangunan atau struktur yang ditinggalkan sebagai ungkapan kebudayaan yang berlaku sesuai jamanya. Berdasarkan pendapat di atas ditarik kesimpulan situs merupakan cagar budaya yang ada di lingkungan sekitar, sehingga peninggalan situs dapat dirawat serta di lindungi.

Salah satu situs yang ada di Kabupaten Madiun adalah situs Masjid Agung Sewulan yang saat ini masih terawat dengan baik, selain itu Masjid Agung Sewulan merupakan peninggalan bersejarah dan termasuk peninggalan bercorak Islam.

\section{Nilai-nilai yang Bisa Diwariskan dari Situs Masjid Agung Sewulan}

Setiap wisatawan yang berkunjung ke Masjid Agung Sewulan memiliki tujuan yang berbeda-beda diantaranya tujuan edukasi maupun tujuan rekreasi untuk melepas penat dalam diri masing-masing wisatawan dan untuk mengetahui suatu objek wisata yang belum pernah dikunjunginya. Namun banyak wisatawan yang berdatangan pada Hari Kamis Malam Jumat dan Tanggal Ganjil untuk berziarah ke Makam Kyai Ageng Basyariah. Namun setiap objek wisata tentunya memiliki nilai-nilai yang bisa 
kita pakai dalam kehidupan sehari-hari, karena nilai tersebut mengandung nilai yang luhur dan nilai kebersamaan, gotong -royong dapat dikenalkan pada siswa sehingga siswa dapat memahami akan pentingnya kebersamaan . Keberadaan Masjid Agung Sewulan secara umum sangat penting. Situs Masjid Agung Sewulan mempunyai nilai - nilai luhur yang harus diwariskan kepada generasi muda.

D. Potensi Masjid Agung Sewulan Sebagai Sumber Belajar

Potensi yang dapat dipelajari oleh siswa dari asitektur masjid yang merupakan bangunan kuno tersebut serta dengan lingkungan yang ada di sekitar. Dengan adanya kolam yang berada di depan masjid tersebut dapat memberikan contoh dalam pembelajaran bahwa dahulunya masyarakat yang akan menjalankan ibadah tersucikan terlebih dahulu sebelum menjalankan ibadah. Ciri khas dari masjid ini akan keunikan bangunan, adanya pintu gapura di setiap gang masuk masjid, adanya kolam diseklilingnya, serta makam yang berada di belakang masjid.

Potensi yang dapat di pelajari bawa dahulunya makam berada di belakang masjid karena, orang yang sudah meninggal akan merasakan doa yang telah di panjatkan oleh keluarganya. Tetapi dengan berkembangnya zaman saat ini jarang sekali di temukan adanya makam di belakang masjid dan ini dapat digunakan sebagai materi pembelajaran.

\section{Daftar Pustaka}

Abdulah. T dan Lapian.A.B. (2010). Indonesia Dalam Arus Sejarah. Jakarta. Ichtiar Baru Van Hoeve.

Alma, B. (2010). Pembelajaran Studi Sosial. Bandung. Alfabeta

Caknur. (2013). Keislaman Yang Hanif. Depok. Paramadina

Darmadi. (2013).Metode Penelitian Pendidikan dan Sosial.

Bandung.Alfabeta

Daulay, H. (2009). Sejarah Pembaharuan dan Pertumbuhan Pendidikan. Jakarta.

Dinas Museum dan Pembugaran Provinsi. Gunawan, R. (2013). Pendidikan IPS Filosofi, Konsep dan Aplikasi. Bandung. Alfabeta.

Hamid, ABD dan Masjid, M. (2011). Pengantar Ilmu Sejarah. Yogyakarta. Ombak

Juliadi. (2007). Masjid Agung Banten.Yogyakarta. Ombak

Kencana Prenada Media Grup

M. Fagan,B. (1993). Berkala Arkelogi Yogyakarta. Arkeologi Yogyakarta

Mas'ud, Z dan Mahmud, M. (2012). Warisan Sumberdaya Arkeologi dan Pembangunan. Yogyakarta. PT Ombak 
Miles, m dan Huberman, A. (1992). Analisis Data Kualitatif. Jakarta. UI-Perss

Moleng, L. (2012). Metode Penelitian Kualitatif. Bandung. PT Rosdakarya

Nzir, M. (2009). Metode Penelitian. Jakarta. Ghalia Indonesia

Sanjaya, W. (2009). Seterategi Pembelajaran Berorientasi Standart Proses Pendidikan. Jakarta. Kencana Prenada Media Grup

Sapria. (2009). Pendidikan IPS. Bandung. PT Remaja Rosdakarya

Silalahi. (2000). Bangunan Cagar Budaya di Provinsi DKI Jakarta. Jakarta.

Sitepu, BP. (2014). Pengembangan Sumber Belajar. Jakarta. PT Raja Grafindo Persada

Slameto. (1991). Proses Belajar Mengajar Dalam Sistem Kredit Semester. Jakarta. Bumi Aksara

Soekmono, R. (1973). Pengantar Sejarah Kebudayaan Indonesia. Penerbit Yayasan Kansius

Soeyono. (2009). Kyai Agung Basyariah (Bagus Harun) Sewulan Dagangan Madiun.

Sudono. (2000). Sumber Belajar dan Alat Permainan. Jakarta. Grasindo

Sugiono. (2001). Metode Penelitian Bisnis. Bandung. Alfabeta

Sugiono. (2008). Metode Penelitian Kuantitatif, Kualitatif dan R\&D. Bandung. Alfabeta
Sugiyono. (2013). Metode Penelitian Kuantitatif, Kualitatif dan $R \& D$. Bandung. Alfabeta

Suherman, E. (2012). Menejemen Masjid Kiat Sukses Meningkatkan Kualitas SDM Melalui Optimalisasi Kegiatan Umat Berbasis Pendidikan Berkualitas Unggul. Bandung. Alfabeta

Sukmadinata, N. (2012). Metode Penelitian Pendidikan. Bandung. PT Remaja Rosdakarya

Sutopo. (2002). Metodologi Penelitian Kualitatif. Surakarta. Sebelas Maret University Perss

Undang-undang Republik Indonesia No. 11 Th. 2010 Tentang Cagar Budaya. (http:///. ‥ Dep kumham.go.id, diunduh 20 Maret 2015 